\title{
Mesenteric ischaemia with massive hepatic portal venous gas
}

\author{
Erwan Oehler, ${ }^{1}$ Marie-Clémence Deniel, ${ }^{2}$ Benjamin Rouget, ${ }^{3}$ Florent Valour ${ }^{1}$
}

${ }^{1}$ Department of Internal Medicine, French Polynesia Hospital Center, Pirae, Tahiti, French Polynesia 2Department of Gastroenterology, French Polynesia Hospital Center, Pirae, Tahiti, French Polynesia ${ }^{3}$ Department of Surgery, French Polynesia Hospital Center, Pirae, Tahiti, French Polynesia

\section{Correspondence to}

Florent Valour,

florent.valour@chu-lyon.fr
To cite: Oehler $\mathrm{E}$, Deniel M-C, Rouget B, et al. BMJ Case Rep Published online: [please include Day Month Year] doi:10.1136/ bcr-2013-200076

\section{DESCRIPTION}

A 67-year-old man with a history of hypertension and atrial fibrillation treated with vitamin $\mathrm{K}$ antagonists presented a melena following non-steroidal anti-inflammatory medication for an acute gout attack. Laboratory findings revealed an international normalised ratio $>10$, requiring vitamin $\mathrm{K}$ administration. Gastroscopy disclosed an erosive oesophagitis (stage III) and a pyloric ulcer (Forrest IIa) treated by proton pump inhibitors. Two days later, he presented an abdominal obstruction syndrome, with abdominal distension, absence of gas and faeces, and fecaloid vomiting. CT scan showed an absence of bowel parietal enhancement, a diffuse pneumatosis intestinalis (figure $1 \mathrm{~A}$ ) and a massive hepatic portal venous gas (HPVG; figure 1A). There was a significant atheromatous obstruction of the upper mesenteric artery ostium (figure 1B). A refractory septic shock with disseminated intravascular coagulation did not allow surgical management, and the patient died a few hours later.

HPVG is a rare imaging finding, associated with intestinal ischaemia in $43-70 \%$ of cases. ${ }^{12}$ In our patient, mesenteric thrombosis had probably been partly triggered by anticoagulant antagonisation, and HPVG worsened by endoscopic procedure. CT scan is the best imaging modality choice for positive and aetiological diagnosis. ${ }^{2}$ Mortality rate remains as high as $30-40 \%$, despite urgent laparotomy required in most patients. ${ }^{13}$

\section{Learning points}

- CT scan is considered as the most accurate imaging modality to diagnose hepatic portal venous gas, a rare imaging finding.

- Mesenteric ischaemia is the most frequent cause of hepatic portal venous gas.

- Urgent laparotomy is required in most cases, and mortality remains as high as $40 \%$.

Contributors All authors contributed to patient management, data collection and manuscript redaction.

Competing interests None.

Patient consent Obtained.

Provenance and peer review Not commissioned; externally peer reviewed.
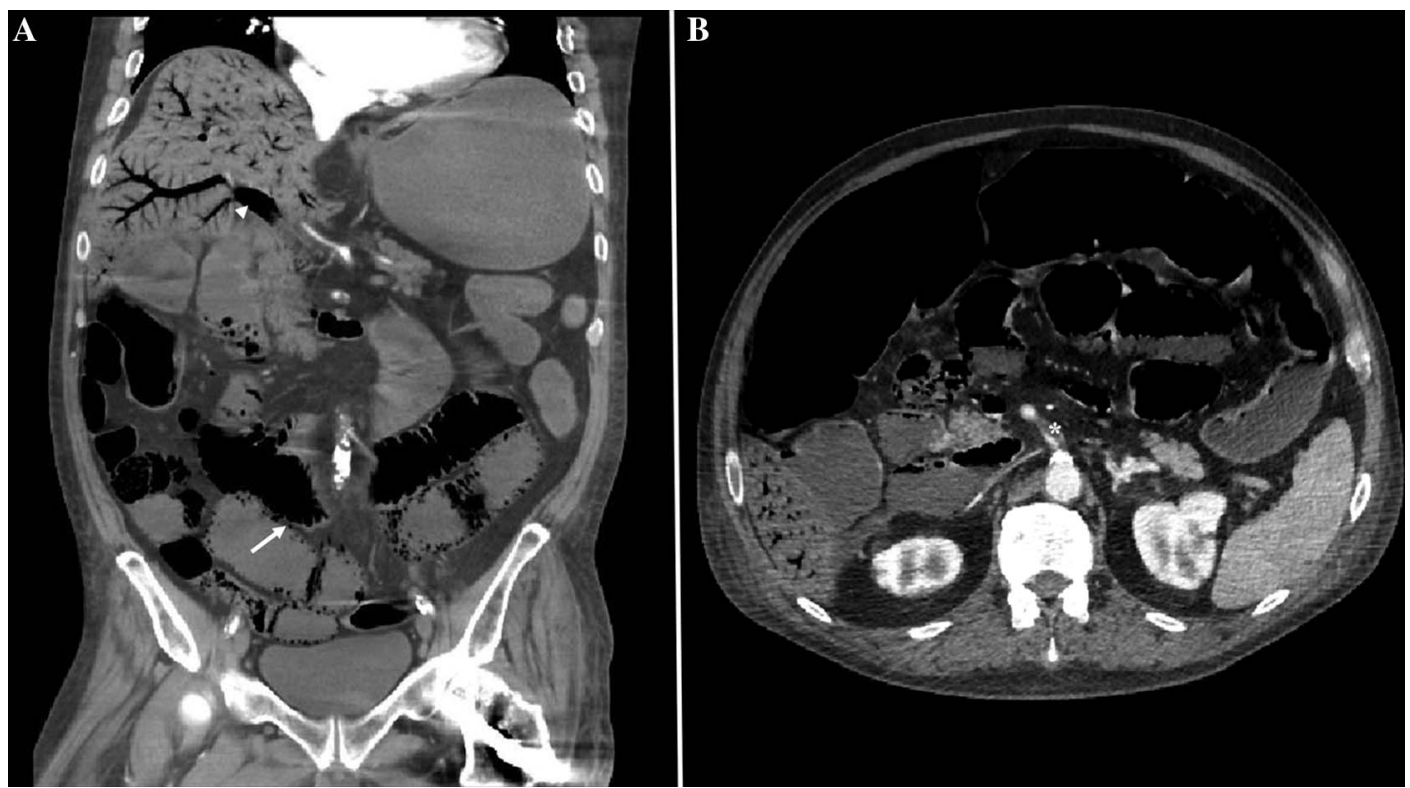

Figure 1 Abdominal CT scan disclosing a diffuse pneumatosis instestinalis ( $A$, arrow) and massive hepatic portal venous gas ( $A$, arrow head), linked with an atheromatous obstruction of the upper mesenteric artery ostium ( $B$, asterisk). 


\section{REFERENCES}

1 McElvanna K, Campbell A, Diamond T. Hepatic portal venous gas - three non-fatal cases and review of the literature. Ulster Med J 2012;81:74-8.
2 Nelson AL, Millington TM, Sahani D, et al. Hepatic portal venous gas: the ABCs of management. Arch Surg 2009;144:575-81.

3 Iannitti DA, Gregg SC, Mayo-Smith WW, et al. Portal venous gas detected by computed tomography: is surgery imperative? Dig Surg 2003;20:306-15.

Copyright 2013 BMJ Publishing Group. All rights reserved. For permission to reuse any of this content visit http://group.bmj.com/group/rights-licensing/permissions.

BMJ Case Report Fellows may re-use this article for personal use and teaching without any further permission.

Become a Fellow of BMJ Case Reports today and you can:

- Submit as many cases as you like

- Enjoy fast sympathetic peer review and rapid publication of accepted articles

- Access all the published articles

- Re-use any of the published material for personal use and teaching without further permission

For information on Institutional Fellowships contact consortiasales@bmjgroup.com

Visit casereports.bmj.com for more articles like this and to become a Fellow 